\title{
The Portfolio as an Evaluation Tool: an Analysis of its Use in an Undergraduate Nursing Program
}

\author{
Denise Barbosa de Castro Friedrich ${ }^{1}$ \\ Angela Maria Corrêa Gonçalves² \\ Tatiana Santos de Sá ${ }^{3}$ \\ Leticia Ribeiro Sanglard ${ }^{3}$ \\ Débora Ribeiro Duque ${ }^{3}$ \\ Gabriela Mota Antunes de Oliveira ${ }^{3}$
}

This qualitative study was carried out between April and August 2007. It analyzed the use of portfolios in the academic community. A total of nine full-time professors and 119 students enrolled in their third semester were interviewed through a semi-structured interview. Content analysis was used to analyze data. Learning evaluations are seen as a verification of knowledge and efficacy of pedagogical method, and also as an incentive to study. Evaluations are procedural, that is, evaluation is continuous, or one-time, e.g. semester end tests. The portfolio is defined as a gradual and continuous evaluation tool. The faculty members and students need to accept the use of portfolios and evaluate the possibilities of this resource. This study is a first attempt to appraise the evaluation process of an undergraduate program, and the use of portfolios and other strategies needs to be consolidated in order to improve the educational process in undergraduate nursing programs.

Descriptors: Education, Nursing; Teaching; Learning.

\footnotetext{
${ }^{1}$ Ph.D. in Public Health, Professor, Faculdade de Enfermagem, Universidade Federal de Juiz de Fora, MG, Brazil. E-mail: denisebcf@yahoo.com.br.

${ }^{2}$ M.Sc. in Nursing, Professor, Faculdade de Enfermagem, Universidade Federal de Juiz de Fora, MG, Brazil. E-mail: gelagon@oi.com.br.

${ }^{3}$ RN. E-mail: Tatiana - tatyenf2006@yahoo.com.br, Leticia - letsanglard@yahoo.com.br, Débora - debora_enf@hotmail.com, Gabriela - gabriesmota@hotmail.com.
}

Corresponding Author:

Denise Barbosa de Castro Friedrich

Universidade Federal de Juiz de Fora. Faculdade de Enfermagem.

Departamento de Enfermagem Materno Infantil e Saúde Pública.

Rua José Lourenço Kelmer, s/n - Campus Universitário

Bairro São Pedro

CEP: 36036-900 Juiz de Fora, MG, Brasil

E-mail:denise.friedrich@ufjf.edu.br 


\section{O portfólio como avaliação: análise de sua utilização na graduação de enfermagem}

Este é um estudo qualitativo, realizado no período de abril a agosto de 2007. O objetivo foi analisar a utilização do portfólio pela comunidade acadêmica. Entrevistaram-se, através de um roteiro, nove docentes efetivos e 119 discentes matriculados a partir do terceiro período. Na análise de dados utilizou-se da análise de conteúdo. A avaliação da aprendizagem é considerada como verificação do conhecimento, como eficácia do método pedagógico e incentivo ao estudo. Com relação aos tipos de avaliação são eles processuais e pontuais. O portfólio é definido como instrumento de avaliação gradual e contínuo. É necessário que o corpo docente e discente aceite experimentar a utilização do portfólio e assim avaliar as possibilidades desse recurso. Representa a primeira aproximação ao processo de avaliação na graduação e, dessa forma, o portfólio e outras estratégias precisam ser consolidadas de forma a melhorar o processo de formação na graduação de enfermagem.

Descritores: Educação em Enfermagem; Ensino; Aprendizagem.

\section{EI Portafolio como evaluación: análisis de su utilización en la graduación de enfermería}

Se trata de un estudio cualitativo, realizado en el período de abril a agosto de 2007. El objetivo fue analizar la utilización del portafolio por la comunidad académica. Se entrevistó a través de un guión a nueve docentes efectivos y 119 discentes matriculados a partir del tercer período. En el análisis de datos se utilizó el análisis de contenido. La evaluación del aprendizaje es considerada como verificación del conocimiento, como eficacia del método pedagógico e incentivo al estudio. Con relación al tipo de evaluación son procesuales y puntuales. El portafolio es definido como un instrumento de evaluación gradual y continuo. Es necesario que el cuerpo docente y discente acepte experimentar la utilización del portafolio y así evaluar las posibilidades de este recurso. Representa una primera aproximación al proceso de evaluación en la graduación y de esa forma el portafolio y otras estrategias necesitan ser consolidadas de forma a mejorar el proceso de formación en la graduación de enfermería.

Descriptores: Educación en Enfermería; Enseñanza; Aprendizaje.

\section{Introduction}

Undergraduate nursing programs educate generalist nurses in light of a set of specific competencies and skills so they can act autonomously or in multi-professional teams in the several realms of professional practice: public or private health facilities, outpatient clinics or in households, at the primary, secondary or tertiary health care levels, either delivering care, or playing administrative and educational roles, or carrying out investigations ${ }^{(1)}$.

For nursing undergraduate students to acquire specific competencies and skills they must perform practical activities (or clinical activities), that is, supervised training in university hospitals or in primary care units. The supervised training is considered by law an activity of social, cultural and professional learning, provided to students of technical and undergraduate programs, who have the opportunity to participate in real life and work situations in their field, held in the general community or in private and public companies under the responsibility and coordination of the educational institution(2).

The current world situation demands qualified professionals with communication and interpersonal relationship skills, and critical-reflective thinking. For 
citizens to assume the role of critical actors they need to develop the ability to understand, which in turn is based on the ability to listen, observe, think, and relate with others and the world. This is so because the job market demands that people be easily adaptable to change and their actual situation, whether by conviction or willingness, without being manipulated, making their critical voice be heard(3).

From this perspective, educational institutions seek ways to evaluate the knowledge of students that are democratic, fair, qualitative and meaningful for students to apply in their daily practice. However, there is strong resistance on the part of society in relation to an innovative evaluation method because it is believed that it would not ensure quality teaching. From this, the question arises of how to explain situations in which students are present, paying attention, and participative but fail to attain satisfactory results. That is why many question the dictates of current evaluation methods, disagreeing with them and exposing their incoherence $^{(4)}$.

In this study, we opted to use the following definition $^{(4)}$ : evaluation is essentially questioning, observing and promoting educational experiences that mean intellectual provocation of the student's development.

It is understood that the evaluation of learning is a teaching resource useful and necessary to help educators and students in the search of and in the process of constructing themselves and devising the best way of being in life. The evaluation process is inclusive, dynamic and constructive. Evaluating is an act by which, through a welcoming posture, we qualify something (an object, action, or person) in order to make a decision on $i^{(5)}$.

The traditional evaluation approach ${ }^{(4)}$ has as its main feature a teacher-centered education; the educator has absolute knowledge and authority. The methodology uses a vertical transmission of knowledge based on oral presentation of planned content and the application of tests, where only the student learns from the teacher. The student assumes the position of mere receiver, being compared to a blank page; his/her experiences and subjective knowledge are not taken into account.

In turn, there is a reversal of roles in the sociocultural approach in which students take an active, curious and social attitude. The heart of education is no longer the teacher and the course's content, it is the student. The learning process departs from the interest of students who are encouraged to construct knowledge, reflect, and think. In this situation, the teacher assumes the role of facilitator of the teaching-learning process to create spaces for dialoguing, sharing responsibilities, fostering constant challenges, encouraging engagement and interaction among students, solidarity, the search for new information, self-assessment, and critical reflection on studied content ${ }^{(4)}$.

The act of evaluation aims to support the permanent inclusion of students in the educational process. The evaluation does not exclude based on a predetermined pattern, but it diagnoses to include, in the search for a more satisfactory, fuller, and qualitatively healthier result(6).

A portfolio is a tool that helps one to develop the ability to reflect, since it is a coherent compilation of documentation thoughtfully selected, significantly commented on and systematically organized and contextualized in time. It is a personal construction, which represents evidence of learning, endowed with unique items ${ }^{(3)}$. It facilitates decision-making, allows a reflexive posture on the part of both the student and teacher and differs from other evaluation processes, as it allows teachers and students a chance to think about their development throughout the course(6).

Data recorded in the portfolio support the teacher and students in their work processes, and in tasks of self-reflection that precede self-assessment. Students learn to reflect on their academic experience and evaluate it. Faculty members, on the other hand, have the opportunity to examine the curricular experience as a whole and provide important and relevant feedback. Thus, it is an important tool for evaluating where students are actively involved, selecting the best samples of their work to include in their portfolios(7).

It can be inferred that the portfolio is a promising proposal, that is, a suitable path for continuous assessment that encourages the development of students with a consequent increase in the level of educational quality.

A study ${ }^{(8)}$ carried out in Chile indicated that participatory methods of teaching are seldom used, demonstrating that innovative tools such as portfolios should be included in the teaching-learning process of nursing programs.

The evaluation method used in the undergraduate program of the School of Nursing - FACENF of a Federal Institution of Higher Education (FIHE) consists of tests to verify knowledge throughout each school year. The FIHE's rating system allows teachers to implement complementary forms of evaluation such as: seminars, case studies, and portfolios, among others. 
The participation of professors in the Specialization Course in Activation Process of Change in Higher Education of Health Professionals, sponsored by the National School of Public Health, Ministry of Health, encouraged these professors in the disciplines: Mental Health Nursing and the Supervised Training I, to adopt portfolios as an assessment tool to monitor the development of knowledge, skills and attitudes of students. From this perspective, a question emerged: How is this form of evaluation used by the academic community?

Based on this question, we chose to carry out this study to analyze the use of portfolios in this academic community.

\section{Method}

A descriptive study using a qualitative approach was chosen to analyze the use of portfolios by professors and students. The setting for this study was the School of Nursing - FACENF of a FIHE.

The FIHE's undergraduate nursing program was founded in 1979 and its mission is to train nurses and human resources in nursing through teaching, research and extension, effectively contributing to promote the health and quality of life of the population within the socio-political-economic context in which it is located. The faculty consists of three departments: Nursing Care; Maternal-Child and Public Health Nursing; and Applied Nursing. In addition to a Bachelor's degree in Nursing, teaching courses in the Faculty of Education are also offered to students.

The study's subjects were nine full-professors professors and 119 students enrolled in the third semester of the nursing program, as these individuals have already had some experience with the use of portfolios and it is believed they had valuable information in relation to this experience. The study's participants were informed of the study objectives and voluntarily consented to participate in the study through a written informed-consent form. Of the total of interviewed students, 105 were female and 14 were male, ages between 22 and 23 years old predominated.

Data were collected through semi-structured interviews previously developed by the researchers and carried out between April and August 2007. The study was approved by the Research Ethics Committee at the FIHE.

Content analysis was used for data analysis. It is based on the generalization of data most frequently obtained and on the content expressed in the reports ${ }^{(9)}$, to demonstrate an excerpt of the interviewees' opinion on the use of portfolios in recorded data, which enabled the construction themes and subthemes.

\section{Results and discussion}

Evaluation of learning in the school of nursing is a process in development as professors and students seek other forms of evaluation, among them the use of a portfolio, as observed in the content analysis of the reports. The themes and subthemes that emerged from the individuals' answers are presented below.

The individuals' answers indicated that the evaluation of learning is considered both a verification of knowledge and of the efficacy of the pedagogical method used.

Evaluation consists of diagnosing an experience; it does not classify nor select; it is inclusive. On the other hand, examining classifies and selects; hence, it excludes. Evaluation has its focus on the construction of the best results possible, while examining is focused on approval or disapproval. Evaluating and examining are virtually opposed $\operatorname{acts}^{(10)}$

Students and professors do not discriminate between evaluation and examination in their daily practice. Tests that approve or disapprove students occur during undergraduate studies, and students and professors act as if they are being evaluated and evaluating, respectively. The following reports demonstrate this idea:

Important, because the student has a clear notion of how was his performance in the course and usually it is the evaluation that makes those students, who are not committed to the course, to study and acquire knowledge (answer student 2).

Necessary, because evaluation should be a tool guiding the learning process, that is, to help the professor to evaluate the method used to mediate the student in the knowledge process (answer professor 2).

In fact, there is a need to break the paradigm of the act of examining in the practice of evaluating the teaching-learning process, since the evaluation guides the pedagogical process and permits one to monitor the learning development and establish goals to be achieved.

The participants' responses also describe evaluation as an incentive to study. The evaluation of a student's learning(11) is directly related to the teaching process; hence, the evaluation should be conducted as another moment in which the student learns. Therefore, it is 
necessary to use this special moment, since the student is engaged in the quest for success. Thus, faced with a culture that holds that tests are a way to encourage studying, why not turn it into a moment of knowledge construction? We can observe this culture expressed in the following quote:

Important. It is a methodology that enables students to test and evaluate the degree of internalization of content addressed in the courses; however, if used as an exclusive form of evaluation, it does not present a reliable portrait of reality in relation to the learning process (answer student 7).

The act of evaluating can be considered a way to encourage studying since the fact of having a scheduled test makes students seek content addressed during the course. However, most students are concerned in achieving the minimum required grade, solely for obtaining approval, not caring about the construction of knowledge that should occur in a continuous and gradual way. It is the role of faculty members to seek strategies that make the act of examining, through tests, something that goes beyond a classificatory and excluding process, as close as possible to the act of evaluating.

FACENF aims to educate generalist nurses in light of a set of specific competencies and skills. The evaluation process in the nursing school allows students to progress throughout the course and it occurs, a priori, through tests to evaluate knowledge, which reiterates the dominant practice in the university, which classifies and excludes ${ }^{(8)}$.

The quality of evaluation in the study in question was between good and regular. Most professors (62.5\%) classified the evaluations carried out in the nursing school as good, while most students (49.6\%) considered them regular.

The quality of evaluation is definitively linked to education and knowledge ${ }^{(12)}$. A quality evaluation should consider the holistic aspect, that is, analyze the various actors involved in the teaching-learning process, take into account their different perspectives and interpretations, and also contribute to self-evaluation.

Thus, to achieve quality evaluation, it is essential that evaluation takes a critical and reflective character, allowing students to go through a process of reflectionaction-reflection. For that, it is necessary that professors take into account the alternative perspectives and different interpretations of other actors in the teachinglearning process: the students.

Regarding the type of evaluation, respondents made a distinction between the formats of evaluation in relation to frequency and regularity in the evaluation system, classifying them into procedural and one-time evaluation.

The procedural evaluation is seen as monitoring the teaching-learning process in a regular and continuous way. This regularity should not be confused with an ongoing evaluation, which is close to the concept that instructors are always evaluating students. In fact, evaluation is always present in the sense that we cannot stop questioning ourselves about the value of what we $\mathrm{do}^{(13)}$.

The one-time evaluation corresponds to an isolated evaluation, which may or not coincide with the final evaluation. Generally, one-time evaluations are not organized to allow a reliable monitoring of the process of students' learning, thus, they do not consist of continuous evaluations. However, we find they are used by most professors, which highlights the need to reformulate teaching practices, since a procedural evaluation depicts the student's process of knowledge construction throughout the course.

The following report shows the existence of two types of evaluation:

In the nursing undergraduate program we have two types of evaluation. Procedural evaluations are those that, in our course, are used during practice. They are, in my view, more reliable evaluations than the one-time evaluations, because they show, in practice, how the student is developing. The one-time evaluations are theoretical tests, which are less reliable, though they are also important (student response 8).

Participants defined one-time evaluations as a type of quantitative evaluation, which does not assess the quality of the teaching-learning process. In addition, they do not portray the real knowledge acquired by students, since they can be influenced by psycho-emotional factors, do not favor the application of knowledge articulated among disciplines, nor the students' development of critical-reflective thinking. Several statements portray such claims:

The one-time evaluations do not reliably portray students' knowledge since they can be influenced by psycho-emotional factors and do not translate the reality of learning (answer student 8 ).

It is a quantitative evaluation that does not evaluate the quality of the teaching-learning process (answer professor 3).

The evaluation needs to be seen as an integrating part of the teaching-learning process and not as something alien that serves only to measure the students' level of knowledge. Evaluation acts during the learning process, both in a procedural form and in a one-time experience. As process, it acts in all activities; as one-time activity 
it offers a diagnosis about the learning results of a given content unit, for instance. That is, in a procedural form, it diagnosis the events of a constructive process; as a one-time activity it diagnosis whether a given process minimally produced the desired result(6). The types of evaluation should not be considered dichotomous, but complementary.

Traditional evaluation aims to verify whether objectives were achieved and whether the content addressed was learned. This type of evaluation is characterized by a period when the professor presents content, and then a test concerning the addressed content is applied.

The traditional method does not take into account what the student constructed and the reality in which the student is placed. The evaluation of learning is considered a process in which creativity or interpretation does not take part. It creates a professor-student relationship, of a professor's authoritarianism and a student's submission, generating a pernicious relationship in the formation of citizens(13). The following answers show that students and professors acknowledge the existence of the traditional method of evaluation:

It's that which follows pre-established standards and rules (answer student 12).

It's an evaluation with a grade; the system requires it to be like this (answer professor 4).

The traditional evaluation is hegemonic in the teaching processes and justified by institutional standards and the educational system. The analysis of the reports allowed us to perceive the sociocultural evaluation, understood here as that in which the student is the subject of his/her learning.

Hence, we question the passive conception of students in the learning process as mere receptors of ready information and a new perspective emerges inside the real meaning of sociocultural evaluation in which the student is an active subject of this process. The following reports illustrate this perspective:

It's the evaluation directed to the student's learning and educational needs without the aim of quantifying knowledge (answer student 10).

[...] it gives the students the opportunity to see and be subjects of learning. It should be an evaluation that includes learning as a whole and not only aspects related to quantitative learning. (Answer professor 5).

These answers show the knowledge of professors and students concerning the sociocultural evaluation, though it does not mean this practice occurs in the studied nursing school.
Portfolios are a tool of diagnostic, procedural evaluation in which students collect activities performed during clinical teaching and supervised training with the purpose to reveal aspects of their knowledge and development, facilitating decision-making, and permitting a reflective attitude both of students and professor/preceptor nurses, in which the professor/ preceptor nurse ask more than answer. This tool differs from other evaluation processes because it gives to those involved the opportunity to reflect on changes that occur throughout the process ${ }^{(5)}$.

A portfolio can be treated ${ }^{(14)}$ as an alternative evaluation tool, capable of overcoming historical conflicts and excessive attachment to grades. The authors ${ }^{(14)}$ argue that the use of portfolios enables emancipatory evaluation practices, consistent with the teaching process, since it must be committed to a critical and reflective education.

To complement this concept, the portfolio can help one to respect and value differences in learning, promoting not just superficial learning, but something that students really feel is theirs and that they can be proud of ${ }^{(15)}$.

The passage from a normative evaluation to a formative(16) one necessarily implies a change in professor practices. It requires from professors an evaluative posture different from the traditional mode(7), requires them to understand that the student is not only the starting point, but also the arrival point. Students' progress can only be perceived when compared with the students themselves: How were they? How are they? The actions developed between the two questions compose the formative evaluation, which can be accomplished through the use of a portfolio.

According to the interviewees, the portfolio can be defined in several ways:

It is an instrument developed during the course in which the student combines material addressed in the classroom, research and knowledge acquired through reports made by students (answer student 13).

A portfolio is like the student's diary. It is where he records his entire evolution, his trajectory. Hence, the student frequently takes notes, has to study all the time, characterizing the learning process as it really is, that is, a continuous process (answer student 12).

[...] it is a resource to record and evaluate learning. I guess that the portfolio gives the student a chance to elaborate and guide the learning process. I guess it also enables the student to address his experience as it is and it enables him to go beyond a quantitative evaluation addressing exclusively acquired 
knowledge, besides helping students to commit to the learning process (answer professor 5).

Given these conceptions, one can infer that these answers portray the portfolio as an instrument of gradual and continuous evaluation. In addition, it is believed that the portfolio is an instrument that enables students to construct their own knowledge and not only be a mere receptor of information. With the use of the portfolio the student is encouraged to seek a theoretical reference to ground his/her reflections, thus s/he is able to enlarge his/her autonomy, with the student becoming the leading figure of the learning process.

A similar study ${ }^{(17)}$ points out that the heterogeneity of professional identities of the faculty members makes changing the pedagogical practice a complex task. The same occurs in FACENF and it is seen in the following reports that show there is not unanimity of opinion in relation to the use of portfolios:

I liked it a lot because it made me realize how my knowledge developed through personal searching (answer student 14).

As a professor, excellent, because it directs the professor and helps to visualize how the student's learning process is and in an apparently less formal way; it keeps the dialogue between student and professor so that the student has in the portfolio a space to self-evaluate, so he poses doubts he wouldn't otherwise for being afraid of exposing them to the class. The student reflects on his learning process while the professor is able to work with qualitative data, he'd not able to through numbers, (answer professor 2).

Boring, because of the subject, had to read texts and more texts on the subject (answer student 18).

I use the portfolio as a resource to develop the teachinglearning process, trying to make the student to use it and understand it, but there are some problems putting it into operation, such as, students complain it's expensive to work with a portfolio and they also may see it as a simple file for keeping material (answer professor 5)

Portfolios are considered a more fair and efficient tool in the evaluation process since it is not a one-time test, rather it continuously evaluates students. However, for its use to achieve the objectives, portfolios must be seen as a tool that helps students and professors in the learning process, allowing follow-up of the students' development and the sharing of experiences. It is not efficacious if it is seen as a mere "file".

\section{Final considerations}

It is be inferred that the success of the portfolio of FACENF depends on it's the real acceptance and participation of those interested in the process, that is, students and professors. If a dialogical relationship, discipline and rigor are not included in its use, the ultimate use of the portfolio is distorted. It is necessary for professors and students to accept using it and evaluate the possibilities of this resource.

This study is a first attempt to appraise the evaluation process of FACENF, hence a new study addressing evaluation processes is suggested including a larger participation of faculty members as the study's subjects and also monitoring the use of portfolios in the courses Mental Health Nursing and the compulsory Supervised Training.

This is a condition necessary not only for the portfolio to be used but for other evaluation strategies to be consolidated in FACENF in order to improve the teaching-learning process in the undergraduate nursing program.

\section{References}

1. UFJF. Descrição da Faculdade de Enfermagem. 2008. [acesso: 03 jul 2008] Disponível em: http://www.enfermagem.ufjf.br. 2. COFEN (BR). Resolução n 299/2005. Dispõe sobre indicativos para a realização de estágio curricular supervisionado de estudantes de enfermagem de graduação e do nível técnico da educação profissional. Brasília (DF): COFEN; 2005.

3. Alarcão I. Professores Reflexivos em uma Escola Reflexiva. 4.ed. São Paulo: Cortez; 2005.

4. Hoffmann J. Avaliar para promover: as setas do caminho. Porto Alegre: Mediação; 2001.

5. Luckesi CC. Avaliação da aprendizagem. Rev Nova Escola 2001 novembro; 1-7 [acesso: 13 jul 2009]. Disponível em: http//www.luckesi.com.br/textos/art_avaliação/art_avaliaçao_ revista_nova_escola2001.pdf
6. Hernandez F. Cultura Visual: mudança educativa e projeto de trabalho. Porto Alegre: Artes Médicas Sul; 2000.

7. Villas Boas,BMF. Portfólio, avaliação e trabalho pedagógico. Campinas: Papirus; 2010

8. Guerrero, VG;Alvarado, OS.Análise dos resultados dos processos de acreditação do curso de enfermagem no Chile. Rev. Latino-Am. Enfermagem. 2010;18(1):94-101, Jan-Fev.2010. [acesso: 28 ago 2010].Disponível em http:/pesquisa.bvsalud. org/regional.

9. Minayo MCS, organizadora. Desafio do Conhecimento: pesquisa qualitativa em saúde. São Paulo: Hucitec; Rio de Janeiro: Abrasco; 1999.

10. Luckesi CC. Avaliação da aprendizagem na escola e a questão das representações sociais Eccos Rev Científica 2002;4(2):79-88. 
11. Moretto VP. Prova: um momento privilegiado de estudo-não uma acerto de contas. Rio de Janeiro: DP\&A; 2002.

12. Demo P. Educação e qualidade. Campinas: Papiro; 1995.

13. Perrenoud P. Avaliação: da excelência à regulação das aprendizagens - entre duas lógicas. Porto Alegre: Artes Médicas Sul; 1999.

14. Sordi MRL, Sampaio SF. O portfolio como recurso de avaliação e seu potencial emancipatório: novos olhares, novos sentidos pedagógicos. $4^{\circ}$ Congreso Internacional Docencia Universitaria e Inovación; 2006; Barcelona. Docencia Universitaria e Inovación. Barcelona; 2006.
15. Gonçalves ML, Andrade AI. Plurilinguismo e Portfolio: um desafio curricular de articulação de saberes. 70 Colóquio sobre Questões Curriculares (30 Colóquio Luso-Brasileiro); Braga, Universidadede Minho, 2006. [acesso: 17 set 2009]. Disponível em: http://portfolio.alfarod.net/doc/artigos/7. Plurilinguismo_e_ Portfolio_2006.pdf

16. Hadji C. Avaliação desmistificada. Porto Alegre: Artes Médicas Sul; 2001.

17. Almino MAFB, Julian IA. Relato de experiência: implantação do portfólio no módulo de Neonatologia num curso de medicina do Ceará. Rev Pediatria. 2007, 8(1). 